\title{
Crise! Crise! Crise! A quebra da Casa Souto nas letras de lundus compostos no Rio de Janeiro na segunda metade do século XIX
}

Silvia Cristina Martins de Souza*

\section{RESUMO}

Este artigo analisa as relaçóes entre história e política, utilizando como fontes as poesias de alguns lundus compostos durante a quebra da casa bancária Souto (Rio de Janeiro, 1864). Defende-se a hipótese de que, ao travarem um "diálogo" em torno do tema, essas poesias expuseram diferentes visóes sobre a crise, encontrando eco entre alguns de seus receptores, que nelas se reconheceram como parte do processo de participação política naquele episódio e foram alguns dos responsáveis pelo sucesso de que as letras desfrutaram, a ponto de serem publicadas em diferentes cancioneiros no Rio de Janeiro da segunda metade do século XIX. Palavras-chave: história; política; lundus; cancioneiros; Rio de Janeiro.

\section{ABSTRACT}

This paper analyzes the relationship between history and politics, using as sources the lyrics of lundus composed at the time of the bankruptcy of Casa Souto, a Rio de Janeiro bank (1864). The hypothesis proposed here is that, by establishing a "dialogue" about the Casa Souto's crisis, these poems exposed different views about it. Some readers recognized themselves in such views, as participants of the political process related to the episode, being therefore responsible for the success of the lyrics, which became very popular and were published in different songbooks in Rio de Janeiro in the second half of the nineteenth century. Keywords: history; politics; lundus; songbooks; Rio de Janeiro.

Artigo recebido em 11 de abril de 2014 e aprovado para publicação em 26 de agosto de 2014.

Este artigo apresenta resultados parciais de um projeto de pesquisa contemplado com uma bolsa do CNPq.

* Doutora pela Universidade Estadual de Campinas (Unicamp) e professora associada da Universidade Estadual de Londrina (UEL). Londrina, PR, Brasil. E-mail: smartins@uel.br. 
Já não se constitui uma novidade afirmar que o Rio de Janeiro oitocentista foi um território rico em experiências musicais. Vários historiadores vêm ressaltando há algum tempo esta faceta da cidade e mostrando que o Rio foi uma cidade polifônica, na qual a música podia ser ouvida em espaços tão diversos como salôes, saraus, teatros, sociedades de bailes, clubes musicais, bailes de carnaval e nos cantos das lavadeiras e dos carregadores negros entoados nas ruas, enquanto executavam seu trabalho. ${ }^{1}$ Nesses locais, a população travou contato com diversos ritmos, gêneros e estilos musicais, desde os mais "nobres", tais como as músicas de câmara, óperas, valsas, mazurcas e varsovianas, até os menos "seletos", como os sons dos cucumbis e dos Zé Pereiras. ${ }^{2}$

Em tal ambiente, a popularização de instrumentos musicais tornou-se um desdobramento quase que natural. Entre esses instrumentos, o mais procurado e desejado foi o piano, que podia ser comprado à vista, de segunda mão, alugado ou adquirido por meio de crédito, nos mais diversificados modelos. ${ }^{3}$

Essa demanda, por sua vez, contribuiu para alavancar o mercado de edição e comércio de coletâneas de partituras musicais (denominados álbuns, ramalhetes e coleçóes), de cancioneiros (coletâneas de letras de cançôes) e de métodos de ensino de piano, flauta e violáo.

Se, para os comerciantes, a busca por diferentes suportes materiais ligados à música foi um fenômeno visto com bons olhos, o sentimento experimentado por outros indivíduos diante deste fenômeno não foi o mesmo. Cardoso de Menezes, provavelmente o crítico musical mais famoso do período, reputou essa situação prejudicial por acreditar que ela favorecia a mistura de ritmos, melodias, vozes e cançôes, colocando em risco a possibilidade de se fazer e cultivar a "boa" música no Brasil. ${ }^{4}$ Uma prova dessa faceta negativa, na sua visão, era que o aumento da edição de partituras musicais colocava nas prateleiras das livrarias "baforadas de música de todo preço, música barata e música de alto coturno", para satisfazer as expectativas de uma cidade na qual não faltava uma casa que tivesse "um piano, uma flauta,

\footnotetext{
${ }^{1}$ Ver, dentre outros, AUGUSTO, Antonio José. A questão Cavalier: música e sociedade no Império e na República (1846-1914). Rio de Janeiro. Tese (Doutorado) — UFRJ, 2008; LOPES, Antonio; ABREU, Martha; ULHÔA, Martha; VELLOSO, Mônica (orgs.). Música e história no longo século XIX. Rio de Janeiro: Casa de Rui Barbosa, 2011; LEME, Mônica. E "saíram à luz" as novas coleçóes de polcas, modinhas, lundus, etc.: música popular e impressão musical no Rio de Janeiro (1820-1920). Niterói. Tese (Doutorado) — UFF, 2006; MENCARELLI, Fernando A. A voz e a partitura: teatro musical, indústria e diversidade cultural no Rio de Janeiro (1868-1908.). Campinas. Tese (Doutorado) — Unicamp, 2003.

${ }^{2}$ Ver CUNHA, Maria Clementina Pereira. Vários Zés, um sobrenome: as muitas faces do senhor Pereira no carnaval carioca da virada do século. In: CUNHA, Maria Clementina Pereira (Org.). Carnavais e outras f(r) estas: ensaios de história social da cultura. Campinas: Unicamp, 2002; TERRA, Paulo Cruz. Músicas de trabalho no Mundo Atlântico. Revista Outros Tempos, ano 3, n. 3, 2006.

${ }^{3}$ Segundo Luiz Felipe de Alencastro, a partir dos anos 1850 teve lugar uma onda crescente de importaçóes e de investimentos diversificados, fruto da alocação das divisas anteriormente concentradas no financiamento do tráfico de escravos para outros setores do comércio. Dentre os produtos importados mais procurados encontrava-se o piano. ALENCASTRO, Luiz Felipe de. Vida privada e ordem privada no império. In: NOVAES, Fernando (Org.). História da vida privada no Brasil. São Paulo: Companhia das Letras, 1997. v. 2, p. 47. ${ }^{4}$ MENEZES, A. Cardoso de. Gazeta Musical, Rio de Janeiro, Lombaerts e Cia, ano II, n. 3, fev. 1892.
} 
uma rabeca, uma clarineta, um violão e um cavaquinho, e o competente artista ou amador para a correspondente execução".

As impressóes registradas por Cardoso de Menezes estiveram longe de ficar restritas a ele. França Júnior também as partilhou e explicitou num dos seus folhetins da série "Política e Costumes". Segundo ele, a "febre" das polcas, que acometeu a população carioca nos anos 1860, trouxe no seu bojo um aumento significativo de ediçóes de partituras de cançóes que dialogavam entre si em torno de um mesmo assunto, contribuindo para a proliferação de uma produção muitas vezes repetitiva, para a qual a originalidade era menos importante do que as retomadas de temas e títulos que alimentassem esses diálogos. ${ }^{6}$

As falas de Cardozo de Menezes e França Júnior apontam para um assunto que reaparece no conto Um homem célebre, de Machado de Assis. Por meio do personagem Pestana, Machado abordou o que via como uma espécie de fratura no meio cultural brasileiro, perceptível nas dissonâncias vivenciadas por um repertório de música erudita, que estaria "longe de fazer parte de um sistema integrado de autores, obras, público e intérpretes", e a música popular urbana, de caráter anônimo (e muitas vezes coletivo), que despontava "para a repercussão das massas, a identificação com a demanda do público e a normalização da mercadoria".

Das visões desses três autores sobre o processo de crescimento e autonomização do campo musical no Rio de Janeiro, o editor emerge como alguém que estaria mais predisposto a atender aos anseios de um mercado ávido por rápidos retornos financeiros do que a contribuir para a "elevação" do gosto musical. O compositor, por sua vez, aparece como um personagem que se submetia aos apelos de editores gananciosos e de um público despreparado para reconhecer a "boa" música. Ao público, por fim, eles reservavam uma espécie de não lugar e de receptores passivos das estratégias de mercado.

Mesmo guardando as devidas reservas para não tomarmos tais falas como "reflexos" da realidade, nelas não se pode desconsiderar a forma como seus autores atribuíram um papel tão significativo aos compositores e editores, e relegaram ao público um papel menor. De fato, o crescimento do comércio de partituras e instrumentos musicais colaborou para estabelecer uma concorrência acirrada neste ramo de negócio, transformando compositores e editores em agentes efetivos de ampliação do público ouvinte e de consolidação de um mercado em expansão, confirmando a grande complexidade cultural da cidade. ${ }^{8}$ No entanto, a atuação de compositores e editores, como produtores culturais, não é suficiente para explicar

\footnotetext{
${ }^{5}$ Ibid, p. 193-194.

${ }^{6}$ Correio Mercantil, 6 out. 1867.

${ }^{7}$ Ver WISNICK, José Miguel. Machado maxixe: o caso Pestana. In: Teresa: revista de literatura brasileira. São Paulo: Ed. 34, [S.d]. n. 4-5, p. 20.

${ }^{8}$ Ver LEME, Mônica. Isidoro Bevilacqua e Filhos: radiografia de uma empresa de edição musical. In: LOPES, Antônio; ABREU, Martha; ULHÔA, Martha; VELLOSO, Monica (Orgs.). Música e história no longo século XIX. Rio de Janeiro: Casa de Rui Barbosa, 2011. p. 121.
} 
a aceitação e o sucesso de que certas canções desfrutaram. Afinal, os produtos culturais são apropriados à maneira do receptor, o que significa dizer que este não pode ser desprezado como parte constitutiva do processo de transmissão e apropriação de bens culturais, sob o risco de reproduzirmos discursos que relegaram tal dimensão no seu contexto de emergência bem como de comprarmos uma disputa política da época.

Conscientes das limitaçóes que as próprias fontes impóem ao pesquisador, mas também de que as formas de circulação e apropriação fazem parte das interrogações dos historiadores nos dias de hoje, devemos pelo menos tentar avançar nessa direção. Nesse sentido, o quadro que vimos traçando oferece alguns indícios que dão o que pensar. Um deles diz respeito à popularidade de certos gêneros musicais, entre eles os lundus, que interessam particularmente a este artigo.

Inicialmente dançados e cantados em festas populares ou encontros informais nas áreas rurais e urbanas, os lundus foram popularizados pelo teatro de revista, chegando a atingir espaços mais elitizados, tais como os salóes das residências. ${ }^{9}$ A forma como os lundus se disseminaram é, sem dúvida, surpreendente, e alguns historiadores ofereceram explicações convincentes para esse fenômeno. Para Martha Abreu, além das peculiaridades melódicas das cançôes e das performáticas da dança, um dos segredos do sucesso dos lundus residia na íntima relação que suas poesias estabeleciam com questôes prementes do seu tempo, explorando assuntos que chamavam a atenção da população. ${ }^{10}$ Complementando as avaliaçóes dessa historiadora, Fernando Mencarelli observou que a linguagem permeada por humor, ironias maliciosas e letras de duplo sentido, típica das letras dos lundus, foi um componente de peso para sua popularidade, por abrirem espaço para diferentes interpretaçóes sobre os assuntos neles abordados.

Levando em consideração os dados aqui arrolados, nos propomos neste artigo analisar um episódio que ficou conhecido na historiografia como "Crise do Souto", ocorrido no Rio de Janeiro, no ano de 1864. Para a elaboração desta análise, foram utilizadas as partes poéticas de alguns lundus, que tomaram essa crise como fonte de inspiração, e se tornaram

\footnotetext{
${ }^{9}$ Lundu é uma palavra que designa coisas diferentes, mas em geral interligadas, na música brasileira. Ela pode servir para denominar um tipo de dança popular; um tipo de música de saláo e também um tipo de canção folclórica. Para maiores detalhes sobre o lundu, ver SANDRONI, Carlos. Feitiço Decente: transformaçôes do samba no Rio de Janeiro (1917-1933). Rio de Janeiro: Zahar, 2001; ULHOA, Martha. Lundu e prosódia musical: caminhos de pesquisa. In: LOPES, Antonio; ABREU, Martha; ULHÔA, Martha; VELLOSO, Mônica (orgs.). op. cit., p. 69-85.

${ }^{10}$ Ver ABREU, Martha. Outras histórias de Pai João: conflitos raciais, protesto escravo e irreverência sexual na poesia popular, 1880-1950, op. cit.; MENCARELLI, Fernando A. A voz e a partitura: teatro musical, indústria e diversidade cultural no Rio de Janeiro (1868-1908), op. cit. De acordo com Jean-Yves Mollier, na França ocorreu fenômeno semelhante entre os anos de 1880 e 1910. Aproveitando-se das grandes crises políticas que abalaram a Terceira República, tais como o escândalo do canal de Panamá e o caso Dreyfus, dezenas de poetas e cantores populares colocaram estes eventos nas cançóes chamadas de littérature du ruisseau, as quais distribuíam gratuitamente ou vendiam a preços módicos pelas ruas. Ver sobre este assunto MOLLIER, Jean-Yves. A história do livro e da edição. Varia Historia, v. 25, n. 42, p. 523-524, jul./dez. 2009.
} 
populares a ponto de serem publicados em mais de um dos cancioneiros que circularam no Rio de Janeiro na segunda metade do século XIX.

A pesquisa nos arquivos consultados confirmou a inexistência de partituras musicais desses lundus, o que nos restringiu à análise de suas partes textuais. ${ }^{11}$ Embora saibamos que a canção popular não pode ser compreendida apenas como texto, e que o "binômio melodia/texto é a forma mais indicada para se ter como referência” ao lidar com testemunhos históricos dessa natureza, é preciso considerar, tal como observado por Vinci de Moraes, que "muitas vezes as formulações poéticas concedem mais indicaçôes e caminhos que as estritamente musicais", e que seus elementos oferecem "indícios importantes para compreender não somente a canção, mas também parte da realidade que gira em torno dela". ${ }^{12}$

As observaçôes de Vinci de Moraes nos remetem a uma ideia desenvolvida por Roberto Ventura no seu Estilo tropical: história cultural e polêmicas literárias no Brasil. Nesse trabalho, Ventura observou que as polêmicas literárias, travadas no Brasil oitocentista, incorporaram a forma dialógica dos desafios da poesia popular. Segundo ele, é possível perceber-se em tais polêmicas um padrão típico das poesias populares, pelo seu "caráter de réplica e pela necessidade de revide do adversário", por ele denominado "padrão reflexivo". ${ }^{13}$ Avançando nessa mesma direção, Carlos Sandroni observou a presença dessa forma dialógica em várias polcas compostas no século XIX, perceptível nos seus títulos e no sentido paródico das suas letras, sem que isso necessariamente acarretasse uma correspondência no nível musical. ${ }^{14}$

Com base nas observaçóes de Vinci de Moraes, Ventura e Sandroni, procuraremos defender neste artigo a hipótese de que um dos motivos da popularidade desses lundus foi que, ao travarem um "diálogo" entre si, eles expuseram diferentes visóes sobre a crise do Souto, as quais encontraram eco entre diversos receptores, que nelas se reconheceram e se viram contemplados como parte do processo de participação política naquele episódio.

É preciso deixar claro, desde já, que, embora a documentação de que dispomos seja escassa e fragmentada, não devemos abrir mão de tentar analisá-la, uma vez que ela fornece oportunidade para refletirmos sobre um tema ainda pouco explorado por historiadores sociais e culturais. ${ }^{15}$ Em função dessa peculiaridade do corpus documental, será muitas vezes no terreno das possibilidades e da interpretação de interpretaçóes que iremos transitar, como o leitor terá a oportunidade de constatar.

\footnotetext{
${ }^{11}$ A documentação utilizada neste artigo (cancioneiros e partituras) foi localizada no acervo da Divisão de Música e Arquivo Sonoro da Biblioteca Nacional do Rio de Janeiro (DIMAS) e no Arquivo Edgard Leuenroth (Unicamp). Os jornais especializados em música consultados foram O Beijo, O Sorriso, Jornal das Senhoras, Lyra de Apolo e Trovador.

${ }^{12}$ MORAES, José Geraldo Vinci de. História e Música: canção popular e conhecimento histórico. Revista Brasileira de História, São Paulo, v. 20, n. 39, p. 215, 2000.

${ }^{13}$ VENTURA, Roberto. Estilo tropical: história cultural e polêmicas literárias no Brasil. São Paulo: Companhia das Letras, 1991. p. 146.

${ }^{14}$ SANDRONI, Carlos. Feitiço Decente: transformaçōes do samba no Rio de Janeiro (1917-1933), op. cit., p. 70-1.

${ }^{15}$ A crise do Souto tem sido um tema contemplado por historiadores econômicos em trabalhos que priorizam a história das empresas e dos empresários.
} 
Feitas tais observaçôes, resta-nos apresentar a organizaçáo do artigo. Dividido em duas partes, na primeira delas o texto apresenta uma pequena biografia de Antônio José Alves Souto e um relato da crise do Souto, com base na literatura especializada no tema. A segunda parte centra-se nos autores desses lundus, nos cancioneiros em que suas poesias foram publicadas, e apresenta uma interpretação dessas poesias a qual, com certeza, é uma entre outras possíveis de serem feitas sobre elas.

Crise! Crise! Crise! Tal foi o grito angustioso que se ouviu, durante a semana passada, de todos os peitos da populaçáo e de todos os ângulos da cidade. A fisionomia da populaçáo exprimiu sucessivamente o espanto, o terror, o desespero, - conforme cresciam as dificuldades e demorava-se o remédio. Era triste o espetáculo: a praça em apatia, as ruas atulhadas de povo, - polícia pedestre a fazer sentinela, polícia equestre a fazer correrias, — vales a entrarem, dinheiro a sair, — vinte boatos por dia, vinte desmentidos por noite, — ilusões de manhã, decepçóes à tarde, — enfim uma situação táo impossível de descrever como difícil de suportar, — tal foi o espetáculo que se apresentou no Rio de Janeiro durante a semana passada. ${ }^{16}$

Com essas palavras Machado de Assis se referiu à quebra da casa bancária do Souto, um episódio que tomou de assalto os habitantes da corte na manhá do dia 11 de setembro de 1864, e foi definido no relatório do ministro da Fazenda José Pedro Dias Carvalho como "a crise mais formidável que se conhece nos fatos econômicos do Brasil". ${ }^{17}$

Antônio José Alves Souto foi um imigrante português que chegou ao Rio em 1830, com dezesseis anos, e se empregou como caixeiro na Casa Ferreira \& Cohn. Três anos depois, ele começou a trabalhar como corretor de títulos e com operaçóes bancárias. $\mathrm{Na}$ década seguinte, Souto fundou uma firma social voltada para negócios bancários e intermediação em transaçóes de descontos, a que deu o nome de Antônio José Alves Souto \& Co., conquistando paulatinamente uma clientela de prestígio composta por políticos e comerciantes.

A prosperidade dos seus investimentos possibilitou que Souto acumulasse um patrimônio significativo em propriedades rurais e urbanas, ${ }^{18}$ e que ele se transformasse num dos

\footnotetext{
${ }^{16}$ Diário do Rio de Janeiro, 19 set. 1864.

${ }^{17}$ RELATÓRIO do Ministério da Fazenda. 1864. p. 12. Disponível em: <http://brazil.crl.edu/bsd/bsd/ u1546/000018.html>.

${ }^{18}$ Dentre suas propriedades, encontrava-se uma chácara localizada nas proximidades da Quinta Imperial da Boa Vista, na qual Souto construiu sua residência e um zoológico com espécimes da fauna brasileira e animais importados da Europa, Ásia e África, o qual era franqueado à visitação pública aos domingos e feriados.
} 
mais representativos banqueiros do Rio de Janeiro ${ }^{19}$ e numa figura proeminente da sociedade carioca do seu tempo. ${ }^{20}$

Coroando essa trajetória de sucesso, ele foi agraciado com o título de visconde de Souto e com as condecoraçôes de dignitário da Ordem da Rosa e comendador das Ordens de Nosso Senhor Jesus Cristo e de Nossa Senhora da Conceição da Vila de Viçosa, todos concedidos por Portugal, além de ter sido presidente da Sociedade Portuguesa de Beneficência e ter composto o conselho auxiliar de administração da Caixa Econômica e Monte de Socorro.

A solidez de seus negócios era fato largamente alardeado, o que explica o impacto que causou no Rio de Janeiro o fechamento das portas de sua casa bancária, até porque, no dia da sua quebra, não havia qualquer "prenúncio de falência". ${ }^{21}$ Nas palavras da Semana Ilustrada, a notícia foi "incrível". Todavia, concluía o autor anônimo dessa nota, essa catástrofe servia como lição para ver-se que não havia nos tempos modernos "colossos inabaláveis (...) casas reputadas sólidas, fortunas julgadas inabaláveis, viam-se em um momento ameaçadas de total ruína". 22

A notícia do encerramento das atividades da Casa Souto se espalhou como um rastilho de pólvora pela cidade reverberando nos "mais longínquos arrabaldes", e até mesmo ao exterior. ${ }^{23} \mathrm{Na}$ capital do império, de acordo com a Semana Ilustrada, "a inquietaçáo foi grande; o pânico geral. (...) O povo afluiu à rua Direita e à rua da Alfândega. Abalado o crédito geral, todos correram aos bancos (...) para salvar a sua propriedade ou o resto das economias

\footnotetext{
${ }^{19}$ De acordo com Hernán Enrique L. Sáez, tamanha foi a importância da casa bancária do Souto que suas "atividades junto às principais instituiçóes financeiras cariocas chegaram a movimentar 8.000:000\$ nos dias que precederam a crise, volume de recursos superior ao orçamento de 7.652:476\$550 proposto neste mesmo relatório para o exército brasileiro". SÁEZ, Hernán Enrique L. O 11 de setembro de 1864 da praça carioca: a crise do Souto e a transformação da política econômica brasileira. Anais do XXX Encontro da APHES. 2010. p. 1. Disponível em: <www.iseg.utl.pt/aphes30/docs/progdocs/HERNAN\%20SAEZ.pdf>.

${ }^{20}$ Por meio do Almanak Laemmert, pode-se acompanhar o processo de ascensão de Antônio José Alves Souto. Nos anos de 1861 e 1862, seu nome apareceu no item "Capitalistas. Proprietários de prédios, etc.”. A partir de 1863, ele apareceu como negociante no item "Casas Bancárias", e daí, até 1864, seu nome e títulos figuraram juntos a uma companhia comercial situada em um sobrado na rua Direita, número 59. No ano de 1865, o Almanak Laemmert passou a mencionar a liquidação da sua casa bancária. Os dados sobre a vida do Souto foram obtidos em CARREIRA, Liberato de Castro. História financeira e orçamentária do Império do Brasil desde a sua fundação, precedida de alguns apontamentos acerca da sua Independência. Rio de Janeiro: Imprensa Nacional, 1889; BLAKE, Sacramento. Dicionário Bibliográfico Brasileiro. Rio de Janeiro: Tipografia Nacional, 1883-1902; BRASIL. Relatório da comissáo encarregada pelo governo imperial por avisos do 1o de outubro e 28 de dezembro de 1864 a proceder a um inquérito sobre as causas principais e acidentais da crise do mês de setembro de 1864. Rio de Janeiro: Tipografia Nacional, 1865; no Almanak Laemmert, de 1850 a 1865. ${ }^{21}$ Semana Ilustrada, 18 set. 1864.

${ }^{22}$ Idem.

${ }^{23}$ Bancos das províncias de São Paulo, Bahia e Pernambuco sentiram os desdobramentos da quebra da Casa Souto, e em Londres, duas casas bancárias que mantinham transaçóes com a Casa Souto, suspenderam seus pagamentos. Ver BRASIL. Atas do Conselho de Estado Pleno. Terceiro Conselho de Estado, 1857-1864. p. 5. Disponível em: <www.senado.gov.br/publicacoes/anais/pdf/ACE/ATAS5-Terceiro_Conselho_de_Estado_1857-1864.pdf>.
} 
acumuladas". ${ }^{24} \mathrm{O}$ Correio Mercantil registrou impressóes semelhantes às da Semana Ilustrada na seção "Notícias Diversas", e sublinhou o pânico que ela disseminou entre certas "classes da sociedade", que depositaram "suas pequenas economias nas casas bancárias" do Rio. ${ }^{25}$

A pressão dos correntistas e a sequência de saques atingiram estabelecimentos tais como Amaral \& Pinto, Gomes \& Filhos, Montenegro \& Lima, Oliveira \& Bello, Fortinho \& Muniz, Brazilian Portuguese \& Bank, London \& Brasilian Bank, Bahia \& Irmáos, os quais não conseguiram dar conta de tantas retiradas e suspenderam os pagamentos, aumentando ainda mais o clima de incerteza entre a população. ${ }^{26}$

Diante do alastramento da crise, o governo imperial viu-se compelido a intervir na situação. Além da garantia de proteção armada aos bancos, foi deslocado um contingente policial para a residência do visconde de Souto, para evitar possíveis retaliaçóes por parte de alguma vítima de sua bancarrota. ${ }^{27}$

A Sociedade dos Assinantes da Praça do Rio de Janeiro organizou uma comissão que dirigiu um apelo ao imperador, pedindo que fossem tomadas providências. ${ }^{28}$ Uma representação dos membros das diretorias dos Bancos do Brasil e do Banco Rural Hipotecário foi também encaminhada a Pedro II, solicitando decisóes que dessem conta do que denominaram "cataclisma" comercial. ${ }^{29}$

Embora o clima de surpresa fosse disseminado, pelos menos para os que tinham acompanhado "a marcha pouco previdente dos estabelecimentos bancários" e a "demasiada expansão que se deu ao crédito durante os últimos anos", aquela era uma tragédia anunciada. ${ }^{30} \mathrm{~A}$ crí-

\footnotetext{
${ }^{24}$ Semana Ilustrada, 18 set. 1864.

${ }^{25}$ Correio Mercantil, 12 set. 1864.

${ }^{26}$ SÁEZ, Hernán Enrique Lara, op. cit., p. 14.

${ }^{27}$ BRASIL. Atas do Conselho de Estado Pleno. Terceiro Conselho de Estado, 1857-1864, op. cit., p. 5. Para a crise do Souto, ver também SOARES, Sebastiāo Ferreira. Esboço ou primeiros traços da crise comercial da cidade do Rio de Janeiro em 10 de setembro de 1864. Rio de Janeiro: Laemmert, 1864.

${ }^{28}$ Esta corporação defendia os interesses dos grandes negociantes nacionais e estrangeiros do comércio bancário. Ver GUIMARÁES, Carlos Gabriel. A Guerra do Paraguai e a atividade bancária no Rio de Janeiro no período 1865-1870: o caso Banco Rural e Hipotecário do Rio de Janeiro. HEERA, v. 1, p. 7.

${ }^{29}$ Nesta representação argumentava-se que a cessação de pagamentos por casas bancárias "honradas e respeitáveis" arrastava "na sua queda a propriedade agrícola e predial" do país, e repercutia sobre o crédito geral, trazendo "consigo a desconfiança no seu maior auge, e com ela a retração dos capitais". BRASIL. Atas do Conselho de Estado Pleno. Terceiro Conselho de Estado, 1857-1864, op. cit., p. 241. De acordo com Thiago Gambi, "O governo imperial e o Banco do Brasil agiram juntos para salvar a praça. Uma série de decretos governamentais no sentido da flexibilização da emissão de notas e a expansão efetiva dessa emissão por parte do banco, que atuou como emprestador em última instância, contribuíram para arrefecer a crise". GAMBI, Thiago. Projetos políticos e crises econômicas: análise do caso do Banco do Brasil na crise bancária de 1864. Anais da IV Conferência Internacional de História Econômica. p. 8. Disponível em: <cihe.fflch.usp.br/sites/ cihe.fflch.usp.br/files/Thiago\%20Gambi_0>.

${ }^{30}$ RELATÓRIO do Ministério da Fazenda. 1864. p. 15. Disponível em: <http://brazil.crl.edu/bsd/bsd/ u1546/000018.html>. Nesta mesma direção, alguns historiadores argumentam que a quebra de alguma casa bancária importante do império naquele contexto era prevista e que a falência da Casa Souto constituiu-se no ápice de uma situação de crise que a Praça Comercial do Rio de Janeiro viva desde 1860. Ver ANDRADE, Ana Maria Ribeiro de. Souto \& Cia. In: Anais da I Conferência Internacional de História de Empresas. Niterói: UFF, 1991. p. 121.
} 
tica contida na expressão "marcha pouco previdente dos estabelecimentos bancários”, que consta do Relatório do Ministério da Fazenda de 1864, relacionava-se às expectativas que a Lei de 22 de agosto de 1860 alimentara entre a população. Após a definição de planos de melhoria da moeda e de organização do setor bancário, delineados entre 1857 e 1860, e com a entrada em vigor de uma política restritiva, consubstanciada nessa lei, que ficou conhecida pelo nome de Lei dos Entraves, tudo levava a crer que os anos seguintes seriam de relativa estabilidade monetária.

A Lei dos Entraves instituiu uma reforma bancária que autorizou o funcionamento de bancos emissores exigindo a obrigatoriedade da conversão das suas notas em ouro (em moeda ou barras); definiu o limite da emissão até o dobro do fundo disponível e aumentou o controle sobre a constituição de sociedades anônimas, que passaram a depender da autorização do governo e da aprovação da Assembleia Legislativa.

O resultado dessa lei foi que ela forçou os bancos a desistirem do direito de emissão, reservando ao Banco do Brasil o monopólio emissor em todo o império. Mas, a fiscalização visando seu cumprimento demonstrou-se ineficiente, permitindo a abertura de brechas e possibilitando que alguns bancos se arriscassem em transaçóes vultosas e de retornos mais difíceis ou demorados, comprometendo sua liquidez pelas contínuas perdas. Dentre esses bancos destacava-se a casa bancária do Souto.

Procurando evitar um estrangulamento do setor, o Banco do Brasil concedeu empréstimos à Casa Souto, que com ele acumulou uma dívida de vinte e dois mil contos de réis, o correspondente, na ocasião, à metade do seu capital. Porém, diante da impossibilidade de continuar a rolagem da dívida, a Casa Souto foi à falência, provocando um efeito dominó em todo o sistema bancário carioca, já que ela mantinha operaçôes com todos os principais bancos da corte. ${ }^{31}$

De fato, a crise do Souto afetou diferentes setores econômicos e sociais do Rio de Janeiro, mas, se para os banqueiros, grandes comerciantes e ricos, ela teve sérios desdobramentos, para as pessoas comuns seus efeitos foram ainda mais desastrosos, pois, além do comprometimento das suas pequenas economias acumuladas com dificuldade, ela contribuiu para o aumento do custo de vida e do preço dos alimentos, situação essa que se agravou ainda mais com eclosão da Guerra do Paraguai, dois meses após a quebradeira dos bancos.

Diante do quadro traçado, não chega a surpreender que esse clima de turbulência tenha se transformado em fonte de inspiração para composição de letras de lundus que falavam do episódio de forma crítica e, simultaneamente, bem-humorada, assunto que passaremos a abordar a partir de agora. ${ }^{32}$

\footnotetext{
${ }^{31}$ Para a crise bancária de 1864, ver também ORTIGÃO, A. B. de Ramalho. A circulação. Crise do 'Xem-Xem'. Evolução das leis monetárias. Crises de 1857 e 1864. In: Anais do Primeiro Congresso de História Nacional. Rio de Janeiro: IHGB; Imprensa Nacional, 1916. parte IV, p. 465-547.

${ }^{32}$ Além de composições musicais, sabe-se que a crise do Souto inspirou pelo menos uma composição literária. Arthur Azevedo escreveu um conto, intitulado Paga ou morre, que conta a história de um médico que havia
} 
Desde a década de 1860, a publicação de cancioneiros tornou-se comum no Rio de Janeiro. ${ }^{33}$ Direcionados para reuniôes nos salóes, seresteiros, trovadores de rua, tocadores de violáo e para o público feminino, os cancioneiros divulgaram um repertório comum aos teatros e cafés concertos, além de um repertório popular, de autoria desconhecida, cantado em diferentes partes do país.

Os cancioneiros podiam ser encontrados em locais como livrarias, bazares, lojas de papel e alfarrabistas, e adquiridos a preços que variavam de mil a três mil réis. De acordo com Fernando Mencarelli, tamanho foi o sucesso desfrutado por esses cancioneiros que não houve o que náo tivesse tido mais de uma edição. ${ }^{34}$ Mas um deles interessa particularmente a este artigo. Trata-se do Trovador: coleção de modinhas, recitativos, árias, lundus, etc., que foi editado no ano de 1876 pela Livraria Popular e organizado por Antônio José da Silva Teixeira. ${ }^{35}$

Sua primeira edição saiu entre 1865 e 1866, em quatro volumes, organizados por Gualberto Peçanha, Cotrim e Campos, e publicados pela Tipografia Cotrim e Campos. A segunda edição foi publicada em 1876, numa versão aumentada composta por cinco volumes com uma média de 140 páginas cada. $\mathrm{Na}$ apresentação da segunda edição, acentuou-se ser ela o resultado da boa acolhida do público, que recebera a primeira edição "com o devido apreço" do qual, sublinhava-se, ela era digna, "pois em nenhum outro ramalhete poético, e por táo cômodo preço, se encontram reunidas as mais variadas e coloridas flores, tanto brasileiras como portuguesas". ${ }^{36}$

economizado a vida inteira para comprar uma casa e depositara seu dinheiro na Casa do Souto. Quando soube da falência, correu até o banqueiro, ameaçando-o com uma arma, transformando-se no único credor a receber integralmente a importância que poupara. Ver <http://www.superdownloads.com.br/download/30/ paga-morre-artur-azevedo/\#ixzz1Aqrr61O3>.

${ }_{33}$ De acordo com Fernando Mencarelli, este fenômeno não foi específico do Brasil e ocorreu também em Portugal, França e Itália, "revelando o interesse romântico pelos cantos populares, por um lado, e, por outro lado, uma tendência à internacionalização da música popular por intermédio do teatro ligeiro. O que mais chama atenção nessas publicações é o número de exemplares que entraram em circulação". MENCARELLI, Fernando A. Interpretando as cançóes: entre os palcos e as ruas. In: LOPES, Antonio; ABREU, Martha; ULHÔA, Martha; VELLOSO, Mônica (orgs.). Música e história no longo século XIX. Rio de Janeiro, op. cit., p. 308. Mais raramente, os cancioneiros traziam partituras, como foi o caso de CANTARES Brasileiros. Cancioneiro Fluminense. Rio de Janeiro: Jacintho Ribeiro dos Santos, 1900.

${ }^{34}$ MENCARELLI, Fernando A. A voz e a partitura: teatro musical, indústria e diversidade cultural no Rio de Janeiro (1868-1908), op. cit., p. 256.

35 TROVADOR: coleção de modinhas, recitativos, árias, lundus, etc. Rio de Janeiro: Livraria Popular de A. da Cruz Coutinho Editor, 1876. A Livraria Popular surgiu no Rio como propriedade do português Antônio Augusto da Cruz Coutinho, irmão de um conhecido livreiro e editor do Porto de nome Antônio Rodrigues da Cruz Coutinho. A relação de parentesco entre os dois facilitou a vinda de obras de Portugal para o Brasil, traduzidas do francês, mas, a partir dos anos 1870, de originais portugueses, sobretudo, brasileiros. Antônio José da Silva Teixeira era proprietário de uma tipografia e editora no Porto.

${ }^{36}$ Ibid, p. 5. 
Da edição de 1876, que foi utilizada neste artigo, constam quatro lundus que se remetem à crise do Souto. São eles: A quebra dos bancos, Não há trocos miúdos, Já não há trocos miúdos e As notas do tesouro ou os trocos miúdos. ${ }^{37}$

Os lundus A quebra dos bancos e Já não há trocos mińdos eram de autoria de Gualberto Peçanha, um dos organizadores da primeira edição do Trovador, que também publicou lundus, modinhas e recitativos de sua lavra em outros dois cancioneiros - Lyra de Apolo (1896) e $A$ cantora brasileira (1878) —, além de ter escrito uma peça teatral intitulada $O$ guarda nacional aquartelado (1866). Não há trocos miúdos era de autoria de Adeodato Sócrates de Mello, personagem sobre o qual só foi possível saber que morreu em 1868, solteiro, aos 25 anos e vitimado por uma tuberculose. ${ }^{38}$ Por fim, As notas do tesouro ou os trocos miúdos era de autoria de J.C.M. Tupinambá (parte poética) e Januário da Silva Arvellos Filho (parte musical). Tupinambá foi, além de poeta, um dos editores do jornal ilustrado A Pacotilha (1866-1867). ${ }^{39}$ Januário da Silva Arvellos Filho era filho de um regente e compositor musical, cursou o Conservatório de Música, foi organista, professor particular de música e do Colégio Pedro II, além de ter se tornado proprietário de uma loja de música na corte e se dedicado à impressão e comércio de partituras. ${ }^{40}$

As informaçôes levantadas sobre os autores desses lundus permitem elaborar algumas consideraçôes iniciais. Apesar de letrados e participantes do mundo cultural do Rio, nenhum deles chegou a exercer atividades que lhes dessem retornos políticos e financeiros significativos, como de resto era comum aos indivíduos que se dedicavam às letras e música no império. ${ }^{41}$ Este é um dado interessante, pois sugere a existência de um ponto de aproximação entre esses autores e outros homens que, como eles, apesar de terem tido uma educação formal e desfrutarem uma vida relativamente confortável, estavam mais próximos das camadas menos favorecidas da populaçáo do que das mais abastadas, o que pode ajudar a entender a forma como trataram a crise do Souto nas suas poesias e o público-alvo que tinham em mente ao escrevê-las.

A edição do cancioneiro de 1876 informa que os lundus $A$ quebra dos bancos e Já não há trocos miúdos deveriam ser cantados com a melodia de um lundu intitulado Espanta o grande progresso. Ainda de acordo com o Trovador, os versos de Não há trocos miúdos deveriam ser entoados com a melodia do lundu $A$ cor morena. As notas do tesouro ou os trocos miúdos recebeu uma melodia especialmente composta por Arvellos Filho.

\footnotetext{
${ }^{37}$ Espanta o grande progresso foi publicado no volume I desta edição; A quebra dos bancos no volume II, Não há trocos miúdos e Já não há trocos miúdos no volume IV, e As notas do tesouro ou os trocos miúdos no volume V. Não foi localizado nenhum exemplar da primeira edição deste cancioneiro nos arquivos pesquisados.

${ }^{38}$ Diário do Povo, 31 de julho de 1868.

${ }^{39} \mathrm{Ver}<\mathrm{http}: / /$ www.cedap.assis.unesp.br/cat_periodicos/popup/a_pacotilha.html>.

${ }^{40} \mathrm{Ver}<$ http://www.dicionariompb.com.br/januario-da-silva-arvellos-filho/dados-artisticos>.

${ }^{41}$ A dificuldade de sobreviver da literatura foi reiterada por vários homens de letras do período, tais como José de Alencar, Olavo Bilac, Arthur Azevedo e Coelho Neto.
} 
O uso de uma mesma melodia para três letras de lundus diferentes requer maiores investigaçôes. ${ }^{42}$ Espanta o progresso é um lundu de autoria de Teixeira e Souza (poesia) e J.J. Goyano (melodia), bastante conhecido da população carioca, tanto que foi publicado em mais três outros cancioneiros, além do Trovador, a saber, Lyra do Trovador, A Cantora Brasileira e Cantor de Modinhas Brasileiras. ${ }^{43}$ Esse conhecimento público, do qual desfrutou, ajuda a compreender por que da edição do Trovador apenas constasse uma alusão a seu título junto à poesia de $A$ quebra dos bancos. Afinal, de tâo conhecida, sua melodia parecia dispensar maiores apresentaçôes para que rapidamente fosse identificada pelos contemporâneos.

No entanto, essa popularidade não é suficiente para explicar por que Gualberto Peçanha escolheu essa melodia para ser cantada com A quebra dos bancos e Não há trocos miúdos, o que nos leva a procurar uma possível afinidade nas partes poéticas desses lundus. Comecemos, então, pelos versos de Espanta o grande progresso.

Espanta o grande progresso

Dessa nossa capital,

Decresce o bem por momento

Cresce a desgraça e o mal!

A carestia de tudo

De grande já não tem nome,

O pobre morre de fome

De miséria e de trabalho.

Em belos carros

$\mathrm{O}$ rico corre,

O pobre morre

Sem que comer;

Tudo é sofrer

Para a pobreza

\footnotetext{
${ }^{42}$ De acordo com Martha Ulhôa, o uso de uma mesma melodia para diferentes poesias de cançóes foi um fenômeno que também ocorreu na França meados do século XIX. Ver ULHÔA, Martha. Lundu e prosódia musical: caminhos de pesquisa, op. cit., p. 87.

${ }^{43}$ Ver CANTOR de Modinhas Brasileiras: coleçáo completa de lindas modinhas, lundus, recitativos, etc., etc. Rio de Janeiro: Laemmert, 1895; A CANTORA brasileira. Rio de Janeiro: Garnier, 1878; LYRA do Trovador: coleção de modinhas, recitativos, lundus, cançóes, etc. Rio de Janeiro: Livraria J. G. de Azevedo, 1896. O mineiro J. J. Goyano foi professor de música no Colégio Marinho e no Colégio Pedro II, diretor de orquestra nos teatros Ginásio Dramático e São Pedro de Alcântara e diretor de coro da Capela Imperial. Goyano foi um dos parceiros mais constantes de Teixeira e Souza na composição de lundus. Antônio Gonçalves Teixeira e Souza foi autor de lundus, romancista e dramaturgo.
} 
Só a riqueza

Vive contente

Mortal que vive

Do seu trabalho

Não tem um canto

Para agasalho. ${ }^{44}$

Espanta o grande progresso é, como se pode ver, uma crítica ao progresso e seus malefícios para os pobres e os que viviam do trabalho morigerado, submetendo-os a tempos de carestia e de fome, sem que contassem com "um canto para agasalho", ao passo que os que viviam de especulações ou de riquezas acumuladas eram sempre por ele favorecidos.

A quebra dos bancos aborda um tema similar ao de Espanta o progresso, só que a partir da crise que levara à bancarrota dos bancos. Seus versos remetem-se ao rebuliço causado no Rio quando correu,

(...) de boca em boca,

Que o nosso grande banqueiro

Fez ciente a seus credores

Que não tinha mais dinheiro.

Todos lastimam

em cada canto

Vertendo pranto

Amargurado

Vivem agora

em agonias,

Chorando suas

Economias.

Apenas se divulgou

Tal notícia na cidade,

Ficou quase que maluca

${ }^{44}$ TROVADOR: coleção de modinhas, recitativos, árias, lundus, etc., op. cit., v. I, p. 67-70. 
Da população — a metade:

Viu-se grandes e pequenos,

Andar em passo de cão,

Tudo falava e gritava

Houve grande confusão.

Mudaram-se então as cenas

Os ricos ficaram pobres

Os pobres são ricos hoje

Pois trazem consigo os cobres. ${ }^{45}$

Embora, neste lundu, a crise fosse lamentada pelas amarguras e agonias provocadas à população, fazendo todos andarem "em passo de cão", sua maior crítica emergia dos versos "Já se deixa ver então / Que no mundo não há pobres, / Pois os mais necessitados / Tinham juntado bem bons cobres". Na visão do seu autor, a crise invertera papéis, transformando ricos em pobres. E se os pobres eram "ricos hoje", fora por terem tido oportunidade de juntar "bem bons cobres", o que significa dizer que eles de alguma forma também se beneficiaram com as especulaçóes bancárias comuns no contexto anterior à crise, imagem esta que nuanceava a visão de que apenas os ricos eram favorecidos, tal como no lundu Espanta o grande progresso.

Mas, se é que os pobres inicialmente conseguiram tirar algum proveito dos desdobramentos da crise, tal como consta destes versos, a situação logo tomaria outro rumo e os "cobres" desapareceriam da praça, assunto este que aparece no lundu Já não há trocos miúdos, do mesmo Gualberto Peçanha. Estabelecendo uma "conversa” consigo próprio, o autor dizia:

Já não há trocos miúdos

Nesta nossa capital,

Os cambistas são os grandes

Nesta época fatal

Os pobres é que se veem

Em assados e apuros,

Pois desejando miúdos

Hã de pagar grandes juros

${ }^{45}$ TROVADOR: coleção de modinhas, recitativos, árias, lundus, etc. op. cit., v. IV, p. 123-124. 
Até as casas de pasto

As listas têm em letreiro

Dizendo que para comer

Levem trocado dinheiro.

E não sabemos até onde

Tudo isto vai parar,

O certo é que o pobre

Há de — sofrer e calar. ${ }^{46}$

Diferentemente do lundu anterior, neste a imagem da especulação aparece associada apenas aos "grandes", aos "cambistas" da "época atual”, e o pobre reassume o papel de vítima, tal como no lundu Espanta o progresso, o que nos leva a uma questão: o que pode ter contribuído para seu ator mudar sua visão sobre os atingidos pela crise?

A falta de trocos miúdos ou dos "cobres", tal como se dizia na ocasião, logo se tornou uma constante nos meses subsequentes à quebra da Casa Souto, e não surpreende que essa situação não tenha passado despercebida a Gualberto Peçanha. O assunto constou das páginas de vários jornais e chegou a ser pautado numa reunião do Conselho de Estado, ocorrida no dia 9 de novembro de 1864. Nela, foram levantadas e debatidas algumas questóes e propostas soluçóes, dentre elas o desaparecimento dos trocos miúdos da Praça do Rio de Janeiro. $^{47}$

A análise da matéria pelos conselheiros trouxe à tona diferentes interpretaçóes sobre o assunto. $\mathrm{O}$ visconde de Abaeté argumentou que a falta de trocos miúdos era fruto da desconfiança geral, não havendo confiança senão nas notas do Tesouro ou nas moedas de prata que serviam para trocos, concluindo que "quem as obtém, recolhe-as". ${ }^{48} \mathrm{O}$ visconde de Itaboraí sugeriu a substituição de "algumas classes das notas do Tesouro de grande valor por outras de 5, 2, e $1 \$ ”{ }^{49}$ Mas a argumentação mais surpreendente, para o leitor de hoje, foi a do visconde de Jequitinhonha. Nas suas palavras, "não é a primeira vez que há falta de troco. $\mathrm{O}$ povo acha meios de se remediar". 50

Jequitinhonha tinha razão, até certo ponto, pois não era a primeira vez que faltavam "cobres" na praça. As constantes ondas inflacionárias e a forma de o governo lidar com as questôes financeira sempre demonstraram sua maior tolerância e receptividade com os

\footnotetext{
46 TROVADOR: coleção de modinhas, recitativos, árias, lundus, etc., op. cit., v. IV, p. 654-655.

${ }^{47}$ BRASIL. Atas do Conselho de Estado Pleno. Terceiro Conselho de Estado, 1857-1864. op. cit., p. 246.

${ }^{48}$ Ibid, p. 245.

${ }^{49}$ Ibid, p. 248,

${ }^{50}$ Ibid.
} 
interesses dos mais ricos e dos grandes comerciantes, deixando a população, sobretudo a mais pobre, em segundo plano. A falta de trocos miúdos era um indicativo dessa postura, porque os "cobres" eram o dinheiro que circulava entre os menos privilegiados, fossem eles compradores ou pequenos comerciantes que viviam do comércio "a retalho", e sua ausência representava um enorme prejuízo para esses indivíduos. ${ }^{51}$

No contexto da crise, porém, esta se tornou uma questáo mais séria, tanto que nas diferentes formas de encaminhamento apresentadas pelos conselheiros para dar cabo da situação, a emissão das notas miúdas foi consensualmente vista como uma açáo necessária e urgente para por fim ao que parecia "antes efeito de manejo, que de verdadeira deficiência de moeda de troco" e fruto de especulação, da agiotagem e da exportaçáo de divisas para as províncias. ${ }^{52}$ De uma especulação e agiotagem que os relatórios do Ministério da Fazenda e do Inquérito sobre as Causas da Crise, de 1864, creditavam aos banqueiros que, dos seus pontos de vista, não primavam pela segurança nas operações e trabalhavam com a concessão irresponsável de crédito, aumentando o risco das transaçóes por eles realizadas. ${ }^{53}$

Mas essas não foram as únicas versóes sobre a falta de trocos miúdos que circularam naquele contexto. Para o barão de Mauá, por exemplo, o motivo do desaparecimento dos cobres era sim a especulação e a agiotagem. No entanto, lembrava Mauá, essa prática não fora inaugurada pelos banqueiros, mas pelo próprio governo, quando da organização do Banco do Brasil, em 1853. ${ }^{54}$

Já para o autor anônimo de uma matéria intitulada "Trocos miúdos", publicada no jornal A verdade sem rebuço, os responsáveis eram outros. Segundo ele, as causas eram conhecidas e o governo e a polícia delas tinham conhecimento: eram "fruto do atentado de certos estrangeiros adeptos do Souto, com vistas de provocar desordens no país que os hospeda, levando ao desespero uma população excessivamente pacífica". Para dar cabo de tal situação, concluía a nota, o governo deveria tomar medidas administrativas urgentes, mas também averiguar e prender "os autores da trama a que aludimos" e mandá-los "visitar Massamedes, Angola ou Benguela!55 Para esse autor, portanto, os culpados eram os banqueiros estrangeiros, bem como o governo e a polícia, que davam respaldo a atividades por ele vistas como ilícitas.

As versóes sobre a situação eram, sem dúvida, conflitantes, mas todas elas reputavam as causas da situação às atividades especulativas, que também aparecem na letra do lundu $J a ́ a$ não há trocos miúdos, sintetizadas na figura dos "grandes cambistas".

\footnotetext{
${ }^{51}$ Jornal da Vitória, 1ํo set. 1866.

${ }^{52}$ Ibid.

53 BRASIL. Relatório sobre as causas da crise do mês de setembro de 1864, op. cit., p. 40-41.

${ }^{54}$ Ao justificar o jogo das ações realizado pelos bancos, Mauá destacou não entender "por agiotagem a compra e venda de açôes, nem essa animaçáo sensata ou ágio que podem merecer os valores públicos de empresas bem calculadas (...). Sem tal ou qual animaçáo de confiança representada no ágio ou prêmio de açóes tudo esmorece”. ANDRADE, Ana M. R. de. 1864: conflito entre metalistas e pluralistas. Rio de Janeiro. Dissertação (Mestrado) — UFRJ. 1987. p. 143.

${ }^{55} A$ verdade sem rebuço, 14 nov. 1864.
} 
Os cambistas foram personagens constantes nas ruas, lojas, portas dos teatros do Rio de Janeiro oitocentista, nas quais ofereciam aos mais incautos bilhetes de loterias e de teatro que compravam e revendiam até pelo dobro do preço. Suas atividades foram alvo de críticas constantes nos jornais, e quase sempre vinham acompanhadas de cobranças de providências do governo e da polícia. Nelas, alegava-se que as atividades dos cambistas comprometiam a imagem "civilizada" do império, além de produzirem efeitos financeiros negativos para a sociedade. ${ }^{56}$ Os cambistas, por seu turno, não deixavam de responder aos ataques dos quais eram vítimas, tentando fazer crer que quem lucrava com suas atividades eram outros, aos quais na verdade eles serviam, e que eles não passavam de "pobres trabalhadores" que não tinham de onde tirar o "sustento de suas famílias". 57

Ataques e defesas à parte, o certo é que essa atividade era lucrativa a ponto de levar ao enriquecimento indivíduos como Celestino Silva, que, antes de se transformar num empresário teatral de sucesso, atuou como cambista de teatro durante anos, e Vitorino do Amaral e Antônio da Silva Pinto, proprietários da casa bancária Amaral \& Pinto, já aqui citada, aberta com dinheiro por eles acumulado em transaçóes especulativas. ${ }^{58}$ Vê-se, assim, que a menção aos "grandes cambistas", presente nos versos de Gualberto Peçanha, inspirava-se em situaçóes concretas e de conhecimento da população da cidade, e remetia-se a personagens historicamente identificáveis, aos quais os leitores e cantores do seu lundu não devem ter tido dificuldade de reconhecer.

Adeodato Sócrates de Mello participou do "diálogo" dos lundus com o seu Não há trocos miúdos, cujos versos reproduzimos a seguir:

Anda o povo em multidão

Que confusão!

Lastimando o duro fardo!

Sem poder comprar mais nada!

Ai! Caçoada,

Ter dinheiro desprezado.

Quer seus doces bons comer

E beber!

O deus Baco queridinho,

Há de só os adorar,

\footnotetext{
${ }^{56}$ O Gosto, de 5 de agosto de 1843.

${ }^{57}$ Diário do Rio de Janeiro, 12 de setembro de 1856. Para os cambistas ver também Diário do Rio de Janeiro de 26 de junho de 1856 e de 18 de julho de 1858.

${ }^{58}$ Uma nota publicada no jornal $A$ verdade sem rebuço, do dia 27 de novembro de 1864, mencionava explicitamente que Amaral e Pinto, antes de serem banqueiros, tinham sido cambistas.
} 
Sem tocar,

Pois não há mais trocadinho.

Notas grandes aos moçozinhos

Bem janotas e trajados,

Afamados,

Do Tesouro empregadinhos

Estes são bem garantidos

São servidos

De miúdos a fartar

Só não tem os pobrezinhos

Que há de a nota cambiar. ${ }^{59}$

No caso deste lundu, não foi possível estabelecer nenhuma relação entre sua parte poética e a do lundu $A$ cor morena, com o qual deveria ser cantado, cuja poesia, como o próprio título indica, é um elogio à cor "mais feiticeira / Candongueira, / que criou a natureza". ${ }^{60}$ Mas, como observa Carlos Sandroni, se nesses "diálogos" a ausência de uma relação singular não implica a ausência de qualquer relação, somos levados a sugerir que ela deve ser atribuída tanto à popularidade de alguns títulos quanto a uma afinidade entre gêneros musicais precisos, no caso, o lundu.

$\mathrm{Na}$ visão construída por Adeodato Sócrates de Mello na poesia do seu lundu, não só a crise fora um golpe para os mais pobres que, por terem dinheiro "desprezado", viram-se privados da satisfação das necessidades e prazeres mais simples, mas, sobretudo, protegera os janotas bem "trajados" e "afamados", "do Tesouro empregadinhos".

A figura do janota é uma chave de leitura para estes versos, pois esse personagem era bastante popular na cidade, podendo ser encontrado em suas ruas, salóes, bailes e repartiçóes públicas, além de ter sido imortalizado em romances e pelo menos em um recitativo intitulado O Janota, de autoria de João Peçanha, publicado no mesmo cancioneiro que os demais lundus de que trata este artigo. ${ }^{61}$ Nesse recitativo, o janota era definido como alguém que vivia de um emprego público que lhe rendia parcos vencimentos, mas que aparentava viver uma vida folgada e apostava numa imagem bem-cuidada e elegante para alçar voos mais altos, geralmente um casamento com alguma moça ou viúva rica.

\footnotetext{
59 TROVADOR: coleção de modinhas, recitativos, árias, lundus, etc., op. cit., v. IV, p. 642-3.

${ }^{60}$ TROVADOR: coleção de modinhas, recitativos, árias, lundus, etc., op. cit., v. I, p. 13-14.

${ }^{61}$ Este recitativo foi publicado em TROVADOR: coleção de modinhas, recitativos, árias, lundus, etc. op. cit., v. V, p. 17-18; e no cancioneiro SERENATAS e saraus. Rio de Janeiro: Garnier, 1902. v. 2, p. 145-146. Recitativo é um gênero musical no qual, como indica o termo em italiano, o que se canta é mais "recitado" do que cantado. Nele, a parte musical é feita por um solista (com ou sem acompanhamento de instrumentos) e durante as pausas do canto são recitadas poesias.
} 
Ou seja, a figura do janota era associada à ideia de logro e enganação, e ao utilizá-la na poesia do seu lundu, Adeodato Sócrates de Mello lançava mão de significados culturais partilhados com seus leitores para falar de um tema que estava na ordem do dia e ocupava as páginas dos jornais, tal como na matéria publicada no já aqui citado $A$ verdade sem rebuço. Nela, podia-se ler que:

(...) os pobres credores, trabalhadores, viúvas, donzelas, órfãos e famílias que haviam depositado com a melhor boa fé suas fortunas, seus pecúlios de cuja renda se alimentavam [nas casas bancárias falidas], esperam e esperarão pelo primeiro dividendo do seu dinheiro que foi cruelmente dilapidado (...) Mas os falidos banqueiros estão, como diz um deles - melhor do que nunca estiveram - colocados acima da lei, fora da ação da justiça, eles têm casa, cama, mesa, e dinheiro para irem além de suas necessidades!

$30.000 \$ 000$, casa, escravos para a casa Souto, fora a mesada aos caixeiros e a mesa do escritório que continua!

$24.0000 \$ 000$ à casa Gomes!

12:000\$000 à casa Montenegro!

(...) E aqueles que lhe deram na boa fé o seu dinheiro, sofrem necessidades (...)

Pobre povo! Pobres dos roubados! Pobres dos pobres sobre os quais recai à menor falta todo o rigor da lei, todo o furor da autoridade, todo o borrento espantalho da justiça; ao passo que os grandes, os potentados, os ricos, inda mesmo falidos fraudulentamente (...) são colocados acima da lei e têm autorização e amplos poderes para — roubarem, para assassinarem, para salpicar de lama a gente honrada que vive do trabalho!! [grifos no original] ${ }^{62}$

Agiotagem, especulação e falta de trocos miúdos, como se vê, eram temas candentes debatidos em diferentes espaços e a partir de diferentes olhares e sujeitos naquela conjuntura. No caso do lundu Não há trocos miúdos, e de forma similar ao jornal $A$ verdade sem rebuço, a posição política tomada por seus autores era explícita, ainda que abordada de forma diferente. A linguagem dura da matéria do periódico diferia do tom brincalhão utilizado no lundu, sem que isso significasse que este último estivesse desprovido de sentido político. $O$ humor foi a forma encontrada por seu autor para expor as contradiçóes de um governo que, na sua visão, mantinha alguns indivíduos "bem servidos e garantidos", e a outros deixava, como única opção, proverem-se da maneira que pudessem ou, como diria Jequitinhonha, arranjarem os "meios de se remediar".

A "conversa" travada entre $A$ quebra dos bancos, Já não há trocos miúdos e Não há trocos miúdos recebeu o reforço de mais um interlocutor com o lundu As notas do tesouro ou os trocos minidos, de autoria de Tupinambá e Arvellos:

${ }^{62}$ A verdade sem rebuço, 14 de novembro de 1864. 
Fugiram desta cidade

As notas de dez tostôes

Com medo dos paraguaios!

A culpa tem-na os mandóes.

Lá se foram os miúdos

Babau, Sr. Ministro,

É preciso remediar-nos

Neste caso tão sinistro.

Vou mandar imprimir

Quinhentos mil cartóes

Que tenham o mesmo valor

Das notas de dez tostóes

Com eles eu vou abrir

Uma casa de banqueiro,

Com prêmio bem pequeno

Hei de ganhar muito dinheiro.

O governo agradecido

Com este serviço prestado

Me há de dar uma teteia

E uma pensão de cruzado.

Fico rico, muito nobre:

O comércio penhorado,

Com este grande serviço,

Me faz logo deputado. ${ }^{63}$

A menção à guerra, presente nestes versos, nos leva a pensar que este lundu foi composto no início do conflito com o Paraguai, deflagrado dois meses após a quebra dos bancos, inau-

${ }^{63}$ TROVADOR: coleção de modinhas, recitativos, árias, lundus, etc., op. cit., v. IV, p. 715-7. 
gurando um tempo em que se passou a reclamar por "prontas providências para as despesas indispensáveis exigidas pelas circunstâncias extraordinárias do país". ${ }^{64}$

$\mathrm{O}$ conflito exigiu financiamentos que cobrissem despesas adicionais e vultosas num orçamento que não oferecia recursos suficientes para tanto. Como as Câmaras estivessem em recesso e o orçamento não pudesse ser modificado, a solução encontrada foi o financiamento por meio da emissão de bilhetes do Tesouro e apólices da dívida pública. ${ }^{65} \mathrm{~A}$ adoção de tais medidas levou o governo imperial a abandonar a austeridade financeira adotada logo após a crise, levando ao aumento do custo de vida e dos preços dos alimentos, e elevando a inflação ao maior índice atingido desde o começo da década. ${ }^{66}$

$\mathrm{O}$ desparecimento dos trocos miúdos e as dificuldades vivenciadas pelos mais pobres aparecem, mais uma vez nos versos, deste lundu, só que tratados como parte do jogo político levado a cabo pelo governo imperial, que retribuía favores prestados como "uma pensão de cruzado" ou facilitava a alguns indivíduos o acesso a cargos políticos. Ou, dito de outra forma, para seus autores, os jogos políticos colocavam no tabuleiro transaçóes tão ilícitas quanto danosas, como as atividades especulativas, do que decorria seu apelo ao "Sr. Ministro", para que remediasse os pobres "neste caso tão sinistro".

Especulação, favorecimentos pessoais e agiotagem foram temas que afloraram durante a crise, e reverberaram por diferentes setores da sociedade carioca naqueles idos de 1864, das quais as poesias desses lundus são mais um testemunho. Diante dessa constatação, acreditamos ser possível elaborar algumas consideraçóes, à guisa de conclusão, as quais devem ser vistas menos como ponto de chegada e mais como ponto de partida para posteriores incursões no tema.

Da "conversa" travada entre esses lundus, emergiu uma similaridade temática, que foi tratada a partir de diferentes olhares dando origem a diversas interpretaçóes. Mesmo conscientes de que essas poesias dizem mais sobre as visóes de seus autores do que sobre o próprio tema nelas abordado, não podemos desconsiderar que, ao serem reinseridas no seu contexto de produção, elas desvelaram facetas instigantes.

\footnotetext{
${ }^{64}$ Apud GAMBI, Thiago. Projetos políticos e crises econômicas: análise do caso do Banco do Brasil na crise bancária de 1864, op. cit., p. 12.

${ }^{65}$ Ibid. Carlos Gabriel Guimarães observou que "O esforço de Guerra demandou despesas cada vez maiores, que fez com que o governo abandonasse sua ortodoxia através do aumento das emissóes via Tesouro Nacional, que substituiu o Banco do Brasil como agente emissor de notas em 1866, a depreciação do câmbio e os empréstimos externos e internos, esse último com o aumento das emissóes de títulos do governo" (GUIMARÁES, Carlos Gabriel. A Guerra do Paraguai e a atividade bancária no Rio de Janeiro no período 18651870: o caso Banco Rural e Hipotecário do Rio de Janeiro. In: Anais do XXVI Simpósio Nacional de História. ANPUH. São Paulo, 2011. p. 1.). Para Wilma Peres Costa, o endividamento do estado imperial com a guerra, especialmente no tocante à dívida pública, constituiu-se num "divisor de águas" na economia brasileira. Ver COSTA, Wilma Peres. A Questáo Fiscal na Transformação Republicana: Continuidade e Descontinuidade. Economia e Sociedade, IE/Unicamp, n. 10, p. 5-6, out. 1998.

${ }^{66}$ SÁEZ, Hernán Enrique L. O 11 de setembro de 1864 da praça carioca: a crise do Souto e a transformação da política econômica brasileira, op. cit., p. 17.
} 
Dentre estas, a participação no campo da política informal é digna de nota. $\mathrm{O}$ mundo da política, que transbordava dessas poesias, aponta para um interesse disseminado por esse assunto naquele contexto e para realidades diferentes das divulgadas pelas instâncias formais da política sobre e ao longo da crise.

Essa constatação nos leva a outra: as versóes da crise, nelas construídas, parecem ter sido plausíveis, pelo menos para alguns contemporâneos, o que significa dizer que seus significados foram compartilhados por receptores os quais possivelmente foram uns dos que adquiriram as duas ediçóes dos cancioneiros em que foram publicadas, para lê-las solitária ou coletivamente, ou cantá-las em encontros nos quais desfrutavam de momentos de lazer e dos quais a política não estava ausente. E este é um dado também interessante, porque nos leva a pensar que os consumidores desses cancioneiros náo se comportaram como vítimas passivas das estratégias de mercado, como as falas de Cardoso de Menezes, França Júnior e Machado de Assis procuravam fazer crer, e impuseram limites concretos às açôes de editores e compositores. Falar de assuntos que estavam na ordem do dia, privilegiando as experiências e visóes de pessoas comuns, era uma forma de satisfazer as expectativas de uma parcela desse público, dimensão da qual os editores e os compositores pareciam ter consciência, e foi explicitada na apresentação do Trovador, mencionada no início deste artigo. Afinal, "levados pelo desejo de agradar aos amadores da poesia popular" que seus editores decidiram republicar este cancioneiro, decisão esta que, acreditavam, seu público retribuiria "com o devido apreço". ${ }^{67}$

\section{Referências bibliográficas}

A CANTORA brasileira. Rio de Janeiro: Garnier, 1878.

ALENCASTRO, Luiz Felipe de. Vida privada e ordem privada no império. In: NOVAES, Fernando (Org.). História da vida privada no Brasil. Sáo Paulo: Companhia das Letras, 1997. v. 2. ANDRADE, Ana M. R. de. 1864: conflito entre metalistas e pluralistas. Rio de Janeiro. Dissertação (Mestrado) — UFRJ. 1987.

. Souto \& Cia. In: Anais da I Conferência Internacional de História de Empresas. Niterói: UFF, 1991.

AUGUSTO, Antonio José. A questão Cavalier: música e sociedade no Império e na República (1846-1914). Rio de Janeiro. Tese (Doutorado) — UFRJ, 2008.

BLAKE, Sacramento. Dicionário Bibliográfico Brasileiro. Rio de Janeiro: Tipografia Nacional, 1883-1902.

${ }^{67}$ TROVADOR: coleção de modinhas, recitativos, árias, lundus, etc., op. cit., p. 5. 
BRASIL. Atas do Conselho de Estado Pleno. Terceiro Conselho de Estado, 1857-1864. p. 5. Disponível em: <www.senado.gov.br/publicacoes/anais/pdf/ACE/ATAS5-Terceiro_Conselho_de_Estado_1857-1864.pdf >.

- Relatório da comissão encarregada pelo governo imperial por avisos do $1^{\circ}$ de outubro e 28 de dezembro de 1864 a proceder a um inquérito sobre as causas principais e acidentais da crise do mês de setembro de 1864. Rio de Janeiro: Tipografia Nacional, 1865.

CANTARES Brasileiros. Cancioneiro Fluminense. Rio de Janeiro: Jacintho Ribeiro dos Santos, 1900 .

CANTOR de Modinhas Brasileiras: coleção completa de lindas modinhas, lundus, recitativos, etc., etc. Rio de Janeiro: Laemmert, 1895.

CARREIRA, Liberato de Castro. História financeira e orçamentária do Império do Brasil desde a sua fundação, precedida de alguns apontamentos acerca da sua Independência. Rio de Janeiro: Imprensa Nacional, 1889.

COSTA, Wilma Peres. A Questão Fiscal na Transformação Republicana: Continuidade e Descontinuidade. Economia e Sociedade, IE/Unicamp, n. 10, p. 5-6, out. 1998.

CUNHA, Maria Clementina Pereira. Vários Zés, um sobrenome: as muitas faces do senhor Pereira no carnaval carioca da virada do século. In: CUNHA, Maria C. P. (Org.). Carnavais e outras f(r)estas: ensaios de história social da cultura. Campinas: Unicamp, 2002.

GAMBI, Thiago. Projetos políticos e crises econômicas: análise do caso do Banco do Brasil na crise bancária de 1864. Anais da IV Conferência Internacional de História Econômica. p. 0. Disponível em: <cihe.fflch.usp.br/sites/cihe.fflch.usp.br/files/Thiago\%20Gambi_0>.

GUIMARÁES, Carlos Gabriel. A Guerra do Paraguai e a atividade bancária no Rio de Janeiro no período 1865-1870: o caso Banco Rural e Hipotecário do Rio de Janeiro. HEERA, v. 1, p. 7.

. A Guerra do Paraguai e a atividade bancária no Rio de Janeiro no período 18651870: o caso Banco Rural e Hipotecário do Rio de Janeiro. In: Anais do XXVI Simpósio Nacional de História. ANPUH. São Paulo, 2011.

LEME, Mônica. E "saíram à luz" as novas coleçōes de polcas, modinhas, lundus, etc.: música popular e impressão musical no Rio de Janeiro (1820-1920). Niterói. Tese (Doutorado) UFF, 2006.

. Isidoro Bevilacqua e Filhos: radiografia de uma empresa de edição musical. In: LOPES, Antonio; ABREU, Martha; ULHÔA, Martha; VELLOSO, Monica (Orgs.). Música e história no longo século XIX. Rio de Janeiro: Casa de Rui Barbosa, 2011.

LOPES, Antonio; ABREU, Martha; ULHÔA, Martha; VELLOSO, Monica. (Orgs.). Música e história no longo século XIX. Rio de Janeiro: Casa de Rui Barbosa, 2011.

LYRA do Trovador: coleção de modinhas, recitativos, lundus, cançôes, etc. Rio de Janeiro: Livraria J. G. de Azevedo, 1896. 
MENCARELLI, Fernando A. A voz e a partitura: teatro musical, indústria e diversidade cultural no Rio de Janeiro (1868-1908.). Campinas. Tese (Doutorado) - Unicamp, 2003. . Interpretando as cançôes: entre os palcos e as ruas. In: LOPES, Antonio; ABREU, Martha; ULHÔA, Martha; VELLOSO, Mônica (orgs.). Música e história no longo século XIX. Rio de Janeiro: Casa de Rui Barbosa, 2011.

MENEZES, A. Cardoso de. Gazeta Musical, Rio de Janeiro, Lombaerts e Cia, ano II, n. 3, fev. 1892.

MOLLIER, Jean-Yves. A história do livro e da edição.Varia Historia, v. 25, n. 42, jul./dez. 2009, p. 523-524.

MORAES, José Geraldo Vinci de. História e Música: canção popular e conhecimento histórico. Revista Brasileira de História, São Paulo, v. 20, n. 39, p. 215, 2000.

ORTIGÃO, A. B. de Ramalho. A circulação. Crise do 'Xem-Xem'. Evolução das leis monetárias. Crises de 1857 e 1864. In: Anais do Primeiro Congresso de História Nacional. Rio de Janeiro: IHGB; Imprensa Nacional, 1916. parte IV.

SÁEZ, Hernán Enrique L. O 11 de setembro de 1864 da praça carioca: a crise do Souto e a transformação da política econômica brasileira. Anais do XXX Encontro da APHES. 2010. p. 1. Disponível em: <www.iseg.utl.pt/aphes30/docs/progdocs/HERNAN\%20SAEZ.pdf>. SANDRONI, Carlos. Feitiço Decente: transformaçôes do samba no Rio de Janeiro (19171933). Rio de Janeiro: Zahar, 2001.

SERENATAS e saraus. Rio de Janeiro: Garnier, 1902. v. 2.

SOARES, Sebastiáo Ferreira. Esboço ou primeiros traços da crise comercial da cidade do Rio de Janeiro em 10 de setembro de 1864. Rio de Janeiro: Laemmert, 1864.

TERRA, Paulo Cruz. Músicas de trabalho no Mundo Atlântico. Revista Outros Tempos, ano 3, n. 3, 2006.

TROVADOR: coleção de modinhas, recitativos, árias, lundus, etc. Rio de Janeiro: Livraria Popular de A. da Cruz Coutinho Editor, 1876.

ULHÔA, Martha. Lundu e prosódia musical: caminhos de pesquisa. In: LOPES, A.; ABREU, M.; ULHÔA, M.; VELlOSO, M. (Orgs.). Música e história no longo século XIX. Rio de Janeiro: Casa de Rui Barbosa, 2011.

VENTURA, Roberto. Estilo tropical: história cultural e polêmicas literárias no Brasil. São Paulo: Companhia das Letras, 1991.

WISNICK, José Miguel. Machado maxixe: o caso Pestana. Teresa: revista de literatura brasileira. São Paulo: Ed. 34, [S.d]. n. 4-5, p. 20. 